\title{
Stress Analysis, Design Formulation and Optimization of Crankpin of Single Cylinder Four Stroke Petrol Engine
}

\author{
Divyesh B. Morabiya $^{\# 1}$, Amit B. Solanki ${ }^{\# 2}$, Rahul L.Patel ${ }^{\# 3}$, B.N.Parejiya ${ }^{* 4}$ \\ ${ }^{1}$ Asst. Professor, Mechanical Engg.Deptt, C.U.Shah University, Wadhwan city, Gujarat, INDIA \\ ${ }^{2}$ Asst. Professor, Mechanical Engg.Deptt, C.U.Shah University, Wadhwan city, Gujarat, INDIA \\ ${ }^{3}$ Asst. Professor, Mechanical Engg.Deptt, C.U.Shah University, Wadhwan city, Gujarat, INDIA \\ ${ }^{4}$ M.E.Student, Mechanical Engg.Deptt, Gujarat Technological University, Ahmadabad, Gujarat, INDIA
}

\begin{abstract}
Crankshaft of Internal Combustion Engine is a well known phenomenon. The problem of their premature failure has attracted several investigators for over a century. Forces acting on the crankpin are complex in nature. The piston and the connecting rod transmit gas pressure from the cylinder to the crankpin. The crankpin is like a build in beam with a distributed load along its length that varies with crank position. Crankpin is large volume production component for I.C engine. The static analysis is done using FEA Software ANSYS which resulted in the load spectrum applied to crank pin bearing.This load is applied to the FE model in ANSYS, and boundary conditions are applied according to the engine mounting conditions. The validation model of crankpin is coupled with statically and dynamically result of Von misses stress and shear stress are within the limits and Formulation of single objective function is done for the minimization of diameter of crankpin (dc) using three design variables, 1) diameter of crankshaft, 2) length of crankpin, 3) web width and optimise through genetic algorithm optimization technique to investigate weight and cost reduction opportunities. Therefore research work consists of two major sections: 1) Static analysis 2) Optimization of weight and cost reduction and ultimately increase efficiency of engine.
\end{abstract}

Keywords - Crankshaft, Crankpin, Stress Analysis, Weight Optimization, Genetic Algorithm

\section{INTRODUCTION}

Crankshaft is a large component with a complex geometry in the engine, which converts the reciprocating displacement of the piston to a rotary motion with a four link mechanism. Design developments have always been an important issue in the crankshaft production industry, in order to manufacture a less expensive component with the minimum weight possible and proper fatigue strength and other functional requirements. These improvements result in lighter and smaller engines with better fuel efficiency and higher power output.[12]The crankshaft consists of the shaft parts which revolve in the main bearings, the crankpins to which the big ends of the connecting rod are connected, the crank arms or webs (also called cheeks) which connect the crankpins and the shaft parts. Forces acting on the crankpin are complex in nature. The piston and the connecting rod transmit gas pressure from the cylinder to the crankpin. It also exerts forces on the crankpin, which is time varying. The crankpin is like a build in beam with a distributed load along its length that varies with crank position. The crankshaft main journals rotate in a set of supporting bearings ("main bearings") shown in Figure 1.1 causing the offset rod journals to rotate in a circular path around the main journal centers, the diameter of that path is the engine "stroke": the distance the piston moves up and down in its cylinder. The big ends of the connecting rods contain bearings ("rod bearings") which ride on the offset rod journals. [1]

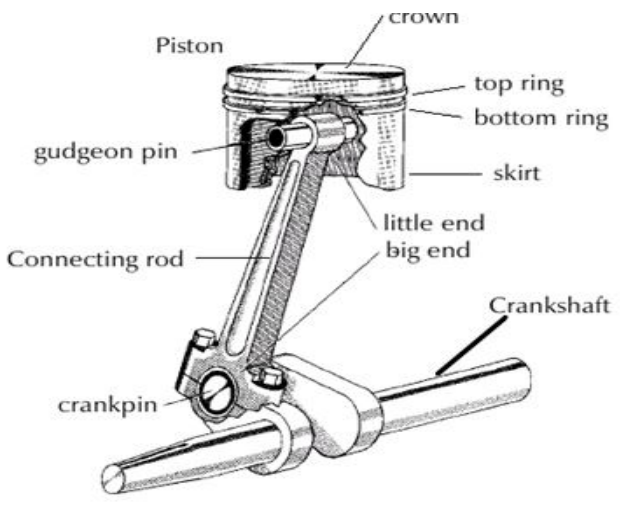

Fig. 1.1 Labelled Image of Engine Components

The objective of this work is for Stress Analysis and Design Optimization of Crankpin of single cylinder four stroke petrol engine and analyzes the stresses acting on crank pin due to the gas force also Analyze the maximum deformation, maximum stress point and dangerous areas of failure. Optimize the design to reduce the rate of failure and improve the life of crank shaft and engine. Design of crankpin is directly related the performance of engine. [3]

\section{DESIGN CALCULATION FOR CRANKPIN}

\begin{tabular}{|l|l|}
\hline Type & Single Cylinder, Petrol engine \\
\hline No of cylinders & 1 \\
\hline Bore/Stroke & $50 \mathrm{~mm} / 55.6 \mathrm{~mm}$ \\
\hline Capacity & $109 \mathrm{cc}$ \\
\hline Compression Ratio & $9: 1$ \\
\hline Max. Power & $8.4 \mathrm{HP} @ 7500 \mathrm{rpm}$ \\
\hline Max. Torque & $8.63 \mathrm{Nm} @ 5500 \mathrm{rpm}$ \\
\hline
\end{tabular}

Table I - Engine Specification 
The material is selected the cast steel for crankshaft and crankpin for which allowable bending stress is $\sigma b=75 \mathrm{~N} / \mathrm{mm}^{2}$ and allowable shear stress is $\tau=35 \mathrm{~N} / \mathrm{mm}^{2}$. [10]

The Allowable bending stress is 56 to $75 \mathrm{MPa}$ and shear stress 31 to $42 \mathrm{MPa}$ for Cast steel. [9]

A. Design of Crankpin [11]

Let, $d c=$ Diameter of crankpin

$l c=$ Length of crankpin

$\sigma b=$ Allowable bending stress for the crankpin $=75 \mathrm{~N} / \mathrm{mm}^{2}$

Bending moment at the centre of the crankpin,

$$
M b=H 1 \times b 2=122.65 \mathrm{kN} \cdot \mathrm{mm}
$$

Also Bending Moment

\section{$d c=30 \mathrm{~mm}$}

$$
M b=\pi / 32 * \mathrm{dc}^{3} * \sigma b
$$

The length of the crankpin is given by $l c=F p / d c \times p b$

Where, $p b=$ Permissible bearing pressure

$$
=5 \mathrm{~N} / \mathrm{mm}^{2} \text { (Assuming) }
$$

$\boldsymbol{l} \boldsymbol{c}=\mathbf{3 8 \mathrm { mm }}$

\begin{tabular}{|c|c|}
\hline Parameter & Dimension (mm) \\
\hline Diameter of crankpin & $30 \mathrm{~mm}$ \\
\hline Length of crankpin & $38 \mathrm{~mm}$ \\
\hline Width of crank web & $42 \mathrm{~mm}$ \\
\hline Thickness of crank web & $22 \mathrm{~mm}$ \\
\hline Diameter of shaft & $35 \mathrm{~mm}$ \\
\hline
\end{tabular}

Table II - Dimension of Crankpin and Crankshaft

\section{MODELLING AND ANALYSIS OF CRANKPIN}

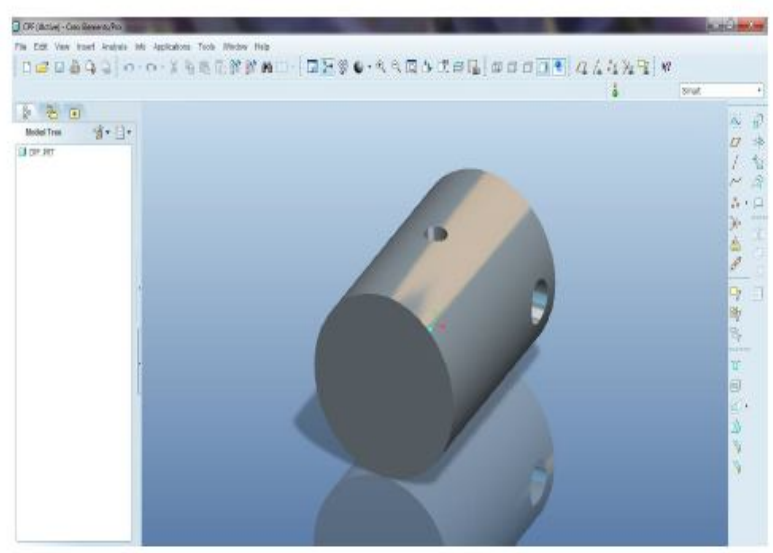

Fig. 2.1 3 D Model of crankpi

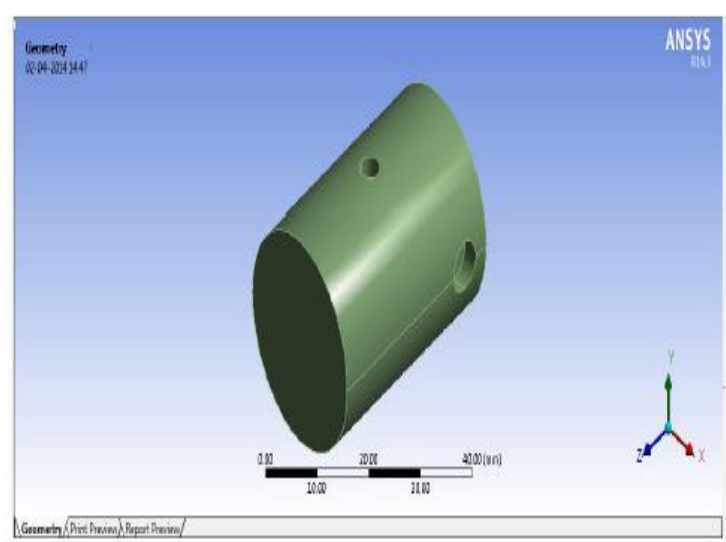

Fig. 2.2 IGES geometry file imported in ANSYS 14.5

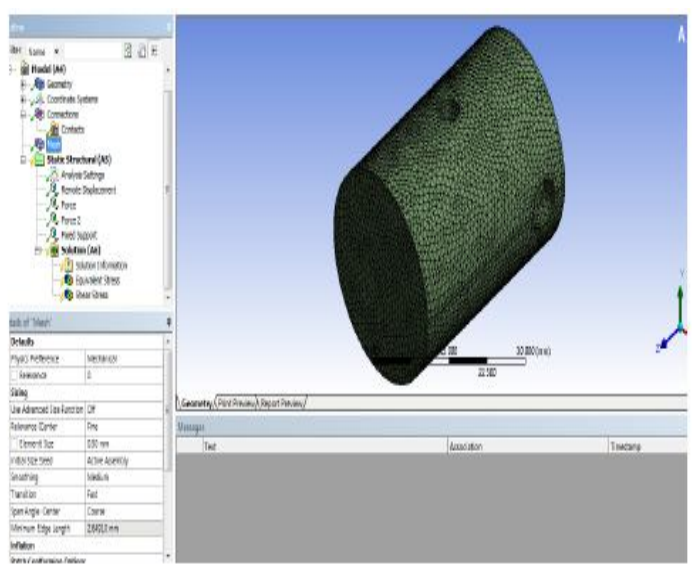

Fig. 2.3 Meshing of crankpin in ANSYS 14.5

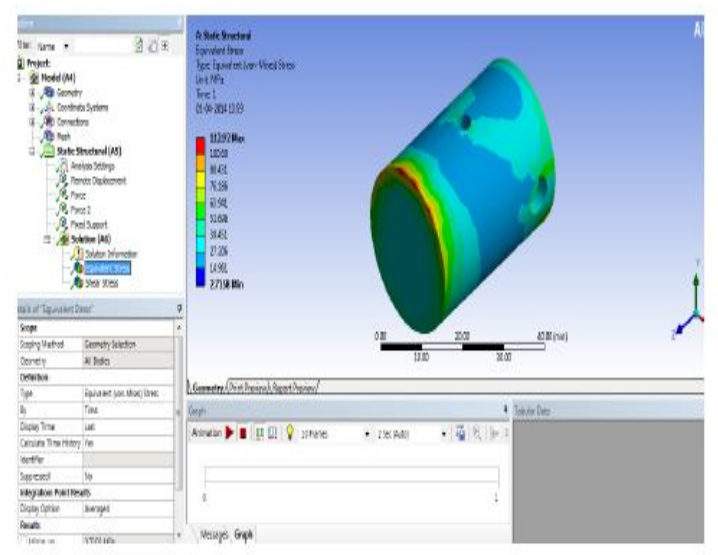

Fig. 2.4 Equivalent Stress results of crankpin 


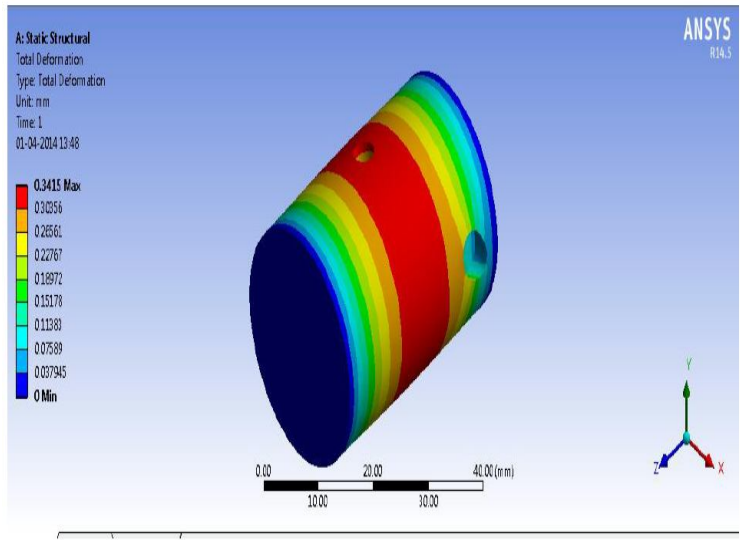

Fig. 2.5 Result of deformation of crankpin

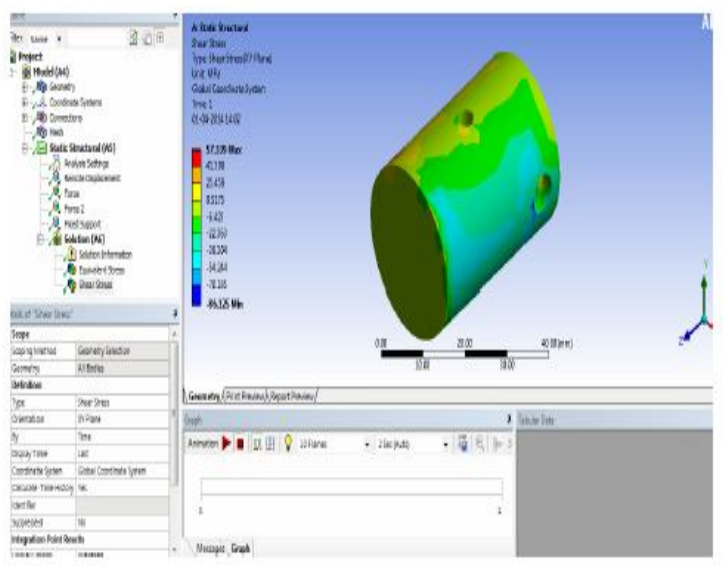

Fig. 2.6 Shear Stress results of crankpin

\begin{tabular}{|c|c|c|c|}
\hline Sr. No. & Types of stress & Theoretical & $\begin{array}{c}\text { FEA } \\
\text { Analysis }\end{array}$ \\
\hline 1 & $\begin{array}{c}\text { Von-Misses } \\
\text { Stresses }\left(\mathrm{N} / \mathrm{mm}^{2}\right)\end{array}$ & 115.96 & 112.92 \\
\hline 2 & $\begin{array}{c}\text { Shear Stresses } \\
\left(\mathrm{N} / \mathrm{mm}^{2}\right)\end{array}$ & 61.71 & 57.339 \\
\hline
\end{tabular}

Table III -Result comparison of theoretical and FEA Analysis

\section{DESIGN OPTIMIZATION METHOD: GENETIC ALGORITHMS}

Genetic algorithms (GA) are search methods that employ processes found in natural biological evolution. These algorithms search or operate on a given population of potential solutions to find those that approach some specification or criteria. [4]
The GA will generally include the three fundamental genetic operations of selection, crossover and mutation. They usually exhibit a reduced chance of converging to local minima. GAs suffer from the problem of excessive complexity if used on problems that are too large. Genetic algorithms work on populations of individuals rather than single solutions, allowing for parallel processing to be performed when finding solutions to the more large and complex problems.[5]

Every member of a population has a certain fitness value associated with it, which represents the degree of correctness of that particular solution or the quality of solution it represents. The initial population of strings is randomly chosen. Although they do not guarantee convergence to the single best solution to the problem, the processing leverage associated with GAs make them efficient search techniques. The main advantage of a GA is that it is able to manipulate numerous strings simultaneously by parallel processing, where each string represents a different solution to a given problem. Thus, the possibility of the GA getting caught in local minima is greatly reduced because the whole space of possible solutions can be simultaneously searched.[6]

\section{FORMULATION}

Problem formulation is normally the most difficult part of the process. It is the selection of design variables, constraints, objective function(s), and models of the discipline/design. Good problem formulation is the key to success of an optimization study.

\section{A. Objective Function}

The objective function is to minimize the diameter of crankpin dc and ultimately reduce the weight of crankshaft

under the effect of static load and so we can reduce the cost.

$$
F(x)=d c=819100 / 60 d s(w ~ l c))^{1 / 3}-10.58
$$

This is the required objective function in three variables when crankshaft subjected to maximum bending moment.

B. Formulation of Constraints

According to summary of manual design result constraints can be enlisted as follows [2]

$$
\begin{aligned}
& \text { - } 24 \leq \mathrm{ds} \leq 35 \\
& \text { - } 20 \leq \mathrm{lc} \leq 38 \\
& \text { - } 30 \leq \mathrm{w} \leq 42
\end{aligned}
$$

Where,

$\mathrm{ds}=$ Diameter of Crankshaft

$\mathrm{dc}=$ Diameter of crankpin

lc $=$ length of crankpin

$\mathrm{w}=$ Width of crank web 


\section{Optimization problem in Standard format}

The above optimization problem in standard format can be stated as below [7]

The design vector $\mathrm{x}=\{\mathrm{ds}, \mathrm{lc}, \mathrm{w}\}$ which minimizes

$$
F(x)=d c=819100 / 60 d s(w ~ l c)^{1 / 3}-10.58
$$

Subjected to constraints,

$$
\begin{aligned}
& \mathrm{g} 1(\mathrm{x})=24-\mathrm{ds} \leq 0 \\
& \mathrm{~g} 2(\mathrm{x})=\mathrm{ds}-35 \leq 0 \\
& \mathrm{~g} 3(\mathrm{x})=20-\mathrm{lc} \leq 0 \\
& \mathrm{~g} 4(\mathrm{x})=\mathrm{lc}-38 \leq 0 \\
& \mathrm{~g} 5(\mathrm{x})=30-\mathrm{w} \leq 0 \\
& \mathrm{~g} 6(\mathrm{x})=\mathrm{w}-42 \leq 0
\end{aligned}
$$

Where,

$\mathrm{ds}=$ Diameter of Crankshaft $\mathrm{dc}=$ Diameter of crankpin lc $=$ length of crankpin $\mathrm{w}=$ Width of crank web

\section{RESULTS}

With the use of MATLAB genetic algorithm tool the fitness function $f(\mathrm{x})$ for the genetic algorithm is calculated with the inequality constraints and the bound limit for the three variables 1) Diameter of the crank shaft, $d_{g} 2$ ) Length of the crank pin, $l_{c}$ 3) web width of crankshaft, $w$.

\section{A. Optimum Design Results using GA}

\begin{tabular}{|c|c|c|c|c|}
\hline SR. & $\begin{array}{c}\text { Width of Web, } \\
(\mathbf{m m})\end{array}$ & $\begin{array}{c}\text { Length of } \\
\text { Crankpin(mm) }\end{array}$ & $\begin{array}{c}\text { Diameter of } \\
\text { Crankshaft(mm) }\end{array}$ & Diameter of \\
Crankpin(mm)
\end{tabular}

Table IV - Optimum Design Results using Genetic Algorithm
B. Summary of Manual Design Results

Diameter of the Crank Pin $=30 \mathrm{~mm}$

Length of the Crank Pin $=38 \mathrm{~mm}$

Diameter of the shaft $=42 \mathrm{~mm}$

Web Thickness (Both Left and Right Hand) $=22 \mathrm{~mm}$

Web Width (Both Left and Right Hand) $=35 \mathrm{~mm}$

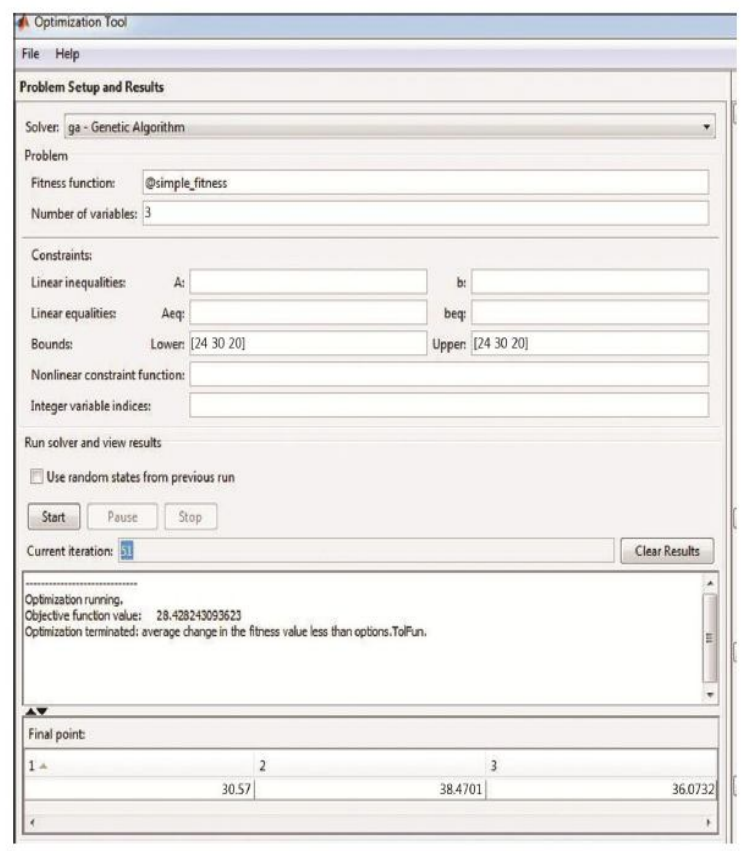

Fig. 6.1 Genetic Algorithm Tool

Figure 6.1 shows the genetic algorithm tool from which the value of the three variables are found with the three points given at the bottom of the toolbox and the fitness function value is found in the centre of the box. Figure 4.2 shows the sample result of GA tool.

Figure 6.2 indicates that the diameter of the crankpin decreases as the width of web decreases and as length of crankpin decreases it will increases up to certain value but after that it will decreases and at the end of limit it will decrease but as the both value of width of web as well as length of crankpin decreases diameter of crankshaft decreases which is seen in figure as the hill portion. The minimum value of diameter of crankpin $28.4 \mathrm{~mm}$ when the width of web $38.47 \mathrm{~mm}$ and length of the crankpin $36.07 \mathrm{~mm}$. 
dc (diameter of crankpin) vs w (width of crankweb) \& lc (length of crankpin)

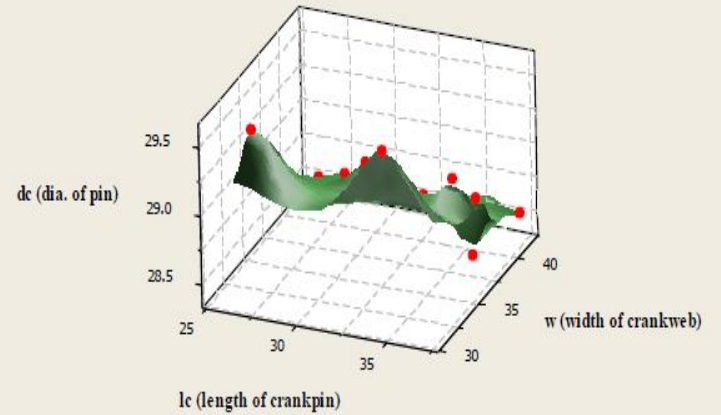

Fig. 6.2 Diameter of Crankpin to width of crank web and Length of Crankpin

dc (diame ter of crankpin) vs w (width of crankweb) \& ds(diameter of shaft)

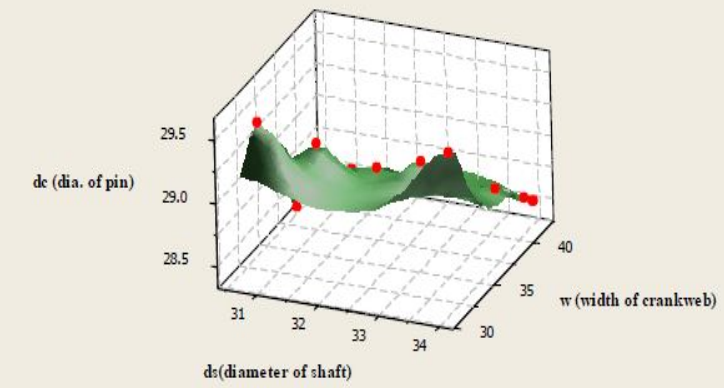

Fig. 6.3 Diameter of crankpin to Web Width and diameter of shaft

dc (diameter of crankpin) vs ds(diame ter of shaft) \& lc (length of crankpin)

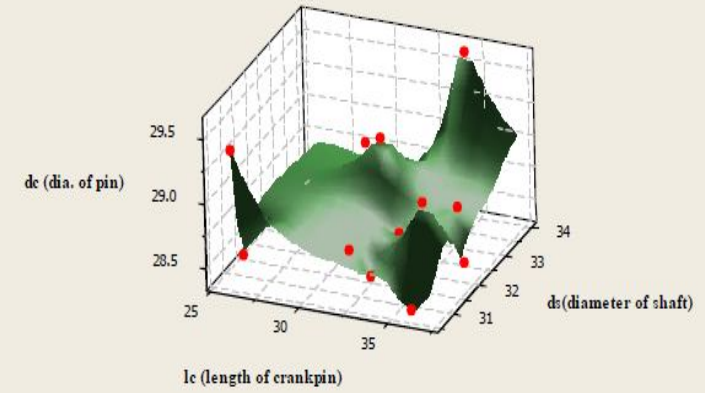

Fig. 6.4 Diameter of Crankpin to diameter of shaft and Length of Crankpin
Figure 6.3 shows that the diameter of the crankpin decreases as the width of web decreases and as diameter of crankshaft decreases it will generate wave form and at the end of limit it will increase but as the both value of diameter of crankshaft and web width decreases and diameter of the crankpin is decreases initially and so that it minimize the value of diameter of the crankpin $28.4 \mathrm{~mm}$ with diameter of crankshaft 30.57 $\mathrm{mm}$ and web width 38.47 which is seen in figure as the hill portion.

Figure 6.4 indicates that the diameter of the crankpin decreases as the length of crankpin decreases and as diameter of crankshaft decreases it will increases up to certain value but after that it will decreases and at the end of limit it will decrease but as the both value of length of crankpin as well as diameter of crankshaft decreases diameter of crankpin decreases which is seen in figure as the hill portion. The minimum value of diameter of crankpin $28.4 \mathrm{~mm}$ when the length of crankpin $36.07 \mathrm{~mm}$ and diameter of crankshaft 30.57 $\mathrm{mm}$.

For validation of the result obtain by the genetic algorithm the other design optimization method is required. Here exhaustive search method validate the result of genetic algorithm and so that from exhaustive search method the results obtain for three variable of the objective function are 1) diameter of crankshaft $31.60 \mathrm{~mm}$, 2) length of crankpin 37.20 $\mathrm{mm} 3$ ) web width $40.50 \mathrm{~mm}$ and with the help of these variable the minimized the diameter of crankpin $29.45 \mathrm{~mm}$. With the help of this it can be seen that the genetic algorithm give very close solution to exhaustive search method and manually design method.

\begin{tabular}{|c|c|c|l|}
\hline \multicolumn{5}{|c|}{ Validation f Result } \\
\hline $\begin{array}{c}\text { Input } \\
\text { Variable }\end{array}$ & $\begin{array}{c}\text { Manually } \\
\text { Design }\end{array}$ & $\begin{array}{c}\text { Genetic } \\
\text { Algorithm }\end{array}$ & $\begin{array}{l}\text { Exhaustive } \\
\text { Search } \\
\text { Method }\end{array}$ \\
\hline $\begin{array}{c}\text { Diameter of } \\
\text { crankshaft } \\
\text { (mm) }\end{array}$ & 35 & 30.57 & $\begin{array}{l}\text { The step of } \\
0.1 \text { i.e. - } \\
31.1-31.2 \\
\text { leads to } \\
\text { ds=31.60 }\end{array}$ \\
\hline $\begin{array}{c}\text { Web width } \\
\text { (mm) }\end{array}$ & 42 & 38.47 & $\begin{array}{l}\text { The step of } \\
0.20 \text { i.e. - } \\
39.20-39.4 \\
\text { leads to } \\
\text { w=40.500 }\end{array}$ \\
\hline $\begin{array}{c}\text { Length of } \\
\text { crankpin } \\
\text { (mm) }\end{array}$ & 38 & 36.07 & $\begin{array}{l}\text { The step of } \\
0.25 \text { i.e. -. } \\
\text { leads to } \\
36 . .25- \\
36.50 \\
\text { lc=37.20 }\end{array}$ \\
\hline \multicolumn{3}{|c|}{ Output } \\
\hline \multicolumn{4}{|c|}{} \\
\end{tabular}




\begin{tabular}{|c|c|c|c|}
\hline $\begin{array}{c}\text { Diameter of } \\
\text { crankpin } \\
(\mathrm{mm})\end{array}$ & 30 & 28.04 & 29.45 \\
\hline
\end{tabular}

Table V - Validation of Results

\section{CONCLUSIONS}

1. Static analysis provides better results than manual calculation. Accurate stresses are input to optimization of the crankpin.FEA Results Conformal matches with the theoretical calculation so we can say that FEA is a good tool to reduce time consuming theoretical Work. The maximum deformation appears at the center of crankpin neck surface. The maximum stress appears at the fillets between the crankshaft journal and crank cheeks and near the central point Journal. The edge of main journal is high stress area. The Value of Von-Misses Stresses that comes out from the analysis is far less than material yield stress so our design is safe and we should go for optimization to reduce the material and cost.

2. The concept design phases aims to find out optimization scheme and confirms structure size. Using different design phases, choosing genetic algorithm will improve analysis efficiency meanwhile save research and development time.

3. A genetic algorithm has been used for the optimum design of crankpin. Some examples of optimum design that minimize the diameter of crankpin under constraints are presented. The numerical results are given in graphical forms of diameter of Crankshaft, length of crankpin, web width. The optimized results are compared with those of exhaustive search method. All the results have the same tendency. Therefore it has a strong possibility for being used for other optimization problems.

A. Formulation

1. Formulation of single objective function is done for the minimization of diameter of crankpin (dc) using three design variables, 1) diameter of crankshaft, 2) length of crankpin, 3) web width.

B. Genetic Algorithm

1. The genetic algorithm only uses the function value and doesn't need derivatives calculated analytically or numerically. 2. The contour plot drawn with the data formed by genetic algorithm, as the value of diameter of crankshaft, length of crankpin and web width decreases the diameter of crankpin.

3. The surface plots give the relationship of diameter of crankshaft to the three parameter and it concludes that the diameter of crankpin is proportional to 1) diameter of crankshaft, 2) length of crankpin, 3) web width.

\section{ACKNOWLEDGMENT}

The support extended by the C.U.Shah University and college authorities is highly appreciated and acknowledged with due respect.

\section{REFERENCES}

[1] Amit Solanki, Ketan Tamboli, M.J.Zinjuwadia, 2011, "Crankshaft Design and optimization- A Review" National Conference on Recent Trends in Engineering \& Technology.

[2] Amit Solanki, P.H. Darji, V.K.Jani, "Optimization of Crankshaft Diameter Using Genetic Algorithm" International Journal For Research In Applied Science and Engineering Technology.

[3] Jaimin Brahmbhatt, Prof. Abhishek choubey, "Design and analysis of crankshaft for single cylinder 4-stroke diesel engine",International Journal of Advanced Engineering Research and Studies E-ISSN2249-8974.

[4] Goldberg, D.E., 1989, "Genetic Algorithm in Search Optimization and Machine Learning", Addison-Wesley Publishing Company Inc., Reading Massachusetts

[5] McCall, J., Genetic algorithms for modelling and optimization, Original Research Article, Journal of Computational and Applied Mathematics, Vol. 184, Issue 1, 1December 2005, Pages 205-222.

[6] Runwei Cheng and Mitsao Gen "Genetic Algorithm and Engineering Optimization" Ashikaga Institute of Technology, John Wiley\& sons. Inc.

[7] S.S.Rao, "Engineering optimization: theory and practice", John Wiley \& Sons, Inc., Hoboken, New Jersey.

[8] Shigley, Joseph E. Mechanical Engineering Design, 3rd edition, 1977 McGraw-Hill.

[9] Design Data, Databook of Engineers, Compiled by PSG college of Technology Coimbatore, Published by Kalaikathir Achchagam Coimbatore (C)1968, Revised edition 1970, Reprinted in January 2010

[10] Dr. P.C. Sharma, Aggarwal, R.D.K, , A Text Book of Machine Design, S. K. Kataraia and sons, New Delhi. 2004

[11] Prof.J.S.Soni, Design of machine elements part-II ,Nirav and Roopal Prakashan, Educational Publishers,Ahmedabad.

[12] B. N. Parejiya, D. B. Morabiya, Amit Solanki "Design and Optimization of Crankpin - A Review" International Journal For Research In Applied Science and Engineering Technology. 